\title{
ВЫЯВЛЕНИЯ НЕГАТИВНОГО ВЛИЯНИЯ ГАЗОБЕТОННОГО БЛОКА В ОРГАНИЗМЕ ЧЕЛОВЕКА
}

\author{
Бруновская Анна Андреевна \\ Бебко София Александровна
}

студенты

Научный руководитель: Климавичус Ярослав Эдвардович

Колледж СамГТУ

Газобетонный блок (газоблок) - это искусственный камень, принадлежащий к семейству ячеистых бетонов, состоящий из кварцевого песка и цемента, который изготавливается с применением технологии газообразования.

Состав газоблоков.

Так же в состав смеси могут входить гипс, известь, шлаки, зола и прочие промышленные отходы.

Для осуществления газообразования пор применяется алюминиевая пудра или паста. Она взаимодействует с известью либо щелочью и выделяет водород. В связи с этим образует поры в рабочей смеси. После ее затвердевания происходит разрезание материала на блоки.

Так же в состав газобетона могут добавлять химическую добавку, такую как Каустическая сода ( Едкий натр), она способствует ускорению газообразования и твердению.

Типы газобетона

Разделяется газобетон по двум типам производства: автоклавный и не автоклавный. Автоклавный газобетон, по другому газосиликатный, он на порядок дороже не автоклавного и применяется для возведении наружных стен. Данный вид подвергается сушке, а так же сушки и твердении в специальном отведенном месте, т. Ж обладает большой прочностью и лучше сохраняет тепло

Газобетон не автоклавного твердения проходит сушку в естественных условиях, обладает меньшей прочностью, а т.ж применяется при монтаже различных перегородок, и подсобных сооружений с последующим нанесением отделочным материалом.

Производство газобетона ( автоклав) 
1. Все компоненты находятся в специальных хранилищах, из которых они поступают в смеситель в заданных оператором количествах.

2. Далее происходит смешивание компонентов до образования однородной массы

3. Следующим этапом является процесс порообразования.

4. После выдержки, блоки проходят через так называемый «горячий тоннель» и отправляются на кантование ( переворачивание груза из формы)

5. Резка единого газобетонного пласта также происходит в автоматическом режиме.

6.Нарезанные установленного размера, блоки отправляются в автоклав, где и происходит завершение процесса производства.

Производство газобетона ( не автоклав)

1. Компоненты перемещаются в газобетоносмеситель в требуемой пропорции.

2. После добавления газообразователя, все ингредиенты смешиваются в течение 10-12 минут.

3. Далее готовая смесь помещается в формы, в которых она выстаивается на протяжении 2-4-х часов с елью завершения процесса газообразования.

4. Все излишки раствора, образованные в связи с увеличением объема, удаляются.

5. Изделия выдерживают еще около 8-ми часов в формах, после чего отправляют сушиться.

6. Для полной технической зрелости и готовности к укладке должно пройти еще не менее 28 дней.

\section{Область применения}

Газобетонные блоки чаще всего применяются для возведения частных домов с этажностью до 3 этажей. Так же строят и жилые здания высотой в 5 этажей, только с жб плитами перекрытия, либо с арматурными поясами.

Также возможно возведение различных технологических зданий и офисных помещений. Сегодня газобетонные блоки часто используют при увеличении этажности старых зданий, поскольку он легок и не дает большой нагрузки на существующие фундаменты и стены.

Положительные и отрицательные качества газобетона.

Плюсы:

Газобетонные блоки легче обычного кирпича в 3-5 раз, что позволяет изготавливать их значительных размеров. Это в свою очередь способствует 
высокой скорости возведения зданий.( К примеру, один строитель может возвести 1 кв. м. стены из газобетонных блоков за 20 минут. В случае с кирпичом этот показатель недостижим.)

Низкая теплопроводность газобетона, которая меньше теплопроводности кирпича в 2-3 раза. Это обусловлено наличием пор, содержащих воздух. (К примеру, при толщине блока 37,5 см., теплоизоляция равна 60-сантиметровой кладке кирпича.)

Легкая обрабатываемость газобетонных блоков сравнима с деревом. Он легко пилится, строгается, сверлится при использовании обычного инструмента плотников.

Высокая огнестойкость материала. Газобетонные блоки негорючие. При этом они способны выдержать воздействие огня с одной стороны на протяжении 3-7 часов.

Высокая паропроницаемость материала благодаря наличию пор. В итоге строение «дышит», обеспечивая оптимальный микроклимат внутри.

Высокая экологичность. Согласно классификации, экологичность материалов определяется специальным коэффициентом. К примеру, у кирпича он составляет 10, у керамзита 20, а у газобетона - 2. Более высокая экологичность лишь у дерева (коэффициент 1).

Минусы:

Из данного материала возможно возводить здания не выше 3 этажей ввиду его ограниченных способностей к сжатию;

Как следствие достаточно высокой впитываемости влаги, газобетон требует дополнительной облицовки внешних стен.

Неавтоклавный газобетон имеет высокий коэффициент усадки, что негативно сказывается на стойкости стен.

Менее экологичный и может нести вред здоровью человека. При добавлении Каустической соды, здоровье человека через какое-то время может ухудшиться.

С иностранными фирмами производящими газобетон ситуация проще,в открытом доступе можно найти паспорт безопасности химической продукции, в котором обязаны указываться химические вещества входящие в состав этого продукта,которые относятся к категории !опасно! В паспорте безопасности можно увидеть не только вредные вещества,но и их процентное и объёмное содержание, а так же всю информацию о производителе, и месте нахождения завода. Паспорт безопасности оформляется к каждой новой партии продукции! 
В масштабах РФ в производстве газобетона ситуация состоит немного подругому. Российский газобетон не экспортируется в страны Европы. И поэтому не требуется оформление МСДС по правилам Евросоюза с указанием всех вредных веществ.

В российских МСДС нет строгого контроля за веществами находящимися в продуктах( в малых количествах).

Поэтому решить данную проблему поможет химическая лаборатория. На основании анализа мы сможем узнать какой производитель газобетона добавляет вредные вещества , вредящие здоровью человека.

Как можно улучшить качество материала?

1. С наружной стороны строение из газобетона нужно облицевать более прочным материалом, чтобы сэкономить на облицовке кирпичом, можно заменить на декоративную водонепроницаемую штукатурку.

2. Так же облагораживают навесными вентилируемыми фасадами. Это придаст дополнительное утепление дома и звукоизоляцию

3. Если к газобетонной стене будут вешать габаритные элементы, то нужно приобрести специальные крепежи, т.к стены хрупки и могут не выдержать.

4. Чтобы улучшить прочность этого материала, можно добавить дисперсную армирующую добавку. В качестве вяжущего целесообразно использовать клинкер, измельченный совместно с песком и минеральными добавками

5. Сравнив зрительно два блока газобетона с добавлением каустической соды и без него, не было выявлено каких-либо отличий.

Поэтому для предотвращения покупки газобетона с опасной для здоровья добавкой, нужно проводить либо выветривание материала, либо отправлять купленный блок в лабораторию , для проведении анализа и состава

\section{Список литературы}

\section{Авторефераты}

1. Айрапетов Г.А. Строительные материалы: учебно-справоч. пособие / Г.А. Айрапетов. М.: Феникс, 2009. 698 с.

2. Технологическая справка о производстве газобетона. / Татьяна Тарасюк

3. Прохоров С.Б., Вишневский А.А. Разработка нового эффективного газообразователя для производства газозолобетона 


\section{Интернет-документы}

4. Применение газобетона в строительстве // http://stroy-gazobeton.ru/9primenenie-gazobetona- $\mathrm{v}$-stroitelstve

5. Оборудование по производству неавтоклавного газобетона // https://www.prostanki.com/board/item/245222

6. Усадка кладки из газобетона // https://www.ytong.ru/daet-li-usadkukladka-iz-gazobetona.php

(C) А.А. Бруновская, С.А. Бебко, 2021 